\title{
Heavy metal pollution of street dust in the largest city of Mexico, sources and health risk assessment
}

\author{
Anahi Aguilera (D) Francisco Bautista • Margarita Gutiérrez-Ruiz • \\ Agueda E. Ceniceros-Gómez · Rubén Cejudo · Avto Goguitchaichvili
}

Received: 26 July 2020 / Accepted: 2 March 2021 / Published online: 16 March 2021

(C) The Author(s) 2021

\begin{abstract}
In large industrialized cities, tons of particles containing heavy metals are released into the environment and accumulate on street surfaces. Such particles cause a potential risk to human health due to their composition and size. The heavy metal contamination levels, main emission sources, and human health risks were identified in 482 samples of street dust. Heavy metal concentrations were obtained by microwave-assisted acid digestion and ICP-OES. The results indicated that street dust in Mexico City is contaminated mainly with $\mathrm{Pb}, \mathrm{Zn}$, and $\mathrm{Cu}$, according to the contamination factor and the geoaccumulation index. The pollution load index of the street dust
\end{abstract}

A. Aguilera $(\triangle)$

Posgrado en Ciencias Biológicas, Universidad Nacional Autónoma de México, Morelia, Michoacán, México e-mail: aaguilera@cieco.unam.mx

\section{A. Aguilera · F. Bautista}

Laboratorio Universitario de Geofísica Ambiental, Centro de Investigaciones en Geografía Ambiental, Universidad Nacional Autónoma de México, Morelia, Michoacán, México

M. Gutiérrez-Ruiz · A. E. Ceniceros-Gómez Laboratorio de Biogeoquímica Ambiental, Facultad de Química, Universidad Nacional Autónoma de México, Mexico City, Mexico

\section{R. Cejudo · A. Goguitchaichvili}

Laboratorio Universitario de Geofísica Ambiental, Instituto de Geofísica Unidad Michoacán, Universidad Nacional Autónoma de México, Morelia, Michoacán, México was made with the concentrations of $\mathrm{Pb}, \mathrm{Zn}, \mathrm{Cu}, \mathrm{Cr}$, and $\mathrm{Ni}$. The main sources of $\mathrm{Pb}, \mathrm{Zn}, \mathrm{Cu}$, and $\mathrm{Cr}$ are anthropic, probably due to vehicular traffic. The highest levels of $\mathrm{Cr}$ and $\mathrm{Pb}$ in urban dust represent a health risk for children. Contamination limits were proposed for heavy metals in street dust of Mexico City. These limits might be useful to generate and apply public policies to decrease anthropic emissions of the heavy metals studied, particularly $\mathrm{Cr}$ and $\mathrm{Pb}$.

Keywords Contamination factor - Pollution load index $\cdot$ Heavy metal loads · USEPA health risk assessment

\section{Introduction}

In several cities around the world, air (Son et al., 2018), soils (Ihl et al., 2015), dusts (Ali et al., 2017; Men et al., 2018; Aguilera et al., 2019), and plant contamination (Aguilar-Reyes et al., 2012) by heavy metals are a serious problem that affects population health (WHO, 2014; Budai \& Clement, 2018). In the case of air and soil contamination, several countries have implemented official standards since decades ago that define the maximum permissible concentrations of heavy metals; however, there is no regulation for street dust and plants.

Street dust is composed of a mixture of naturally occurring pollutants (weathering of rocks, soil erosion, leaf litter, among others) (Cortés et al., 2015) 
and anthropic (brake and tire wear, engine components, and exhaust emissions) (Budai \& Clement, 2018; Gunawardena et al., 2014; Świetlik et al., 2015), as well as polluting particles released by industries (Aguilera et al., 2019), homes, and the weathering of urban infrastructure (Lee et al., 2018). Street dust is a sink of particulate heavy metals that are deposited on the surface of streets, sidewalks, and windows (Rahman et al., 2019). At the same time, street dust can become a source of pollutants by resuspension and washed off by stormwater runoff (Wijesiri et al., 2018).

In particular, the study of street dust is interesting because it is in closer contact with the population than particulate matter (measured at $4 \mathrm{~m}$ above the ground) or soils. Heavy metals in street dust can enter the human body through three routes of exposure: inhalation, ingestion, or dermal. Depending on factors such as toxicity of the element, bioavailability, concentration, etc., as well as socioeconomic issues and the person's health status, heavy metals can generate adverse health effects (Calderón et al., 2001; Carrizales et al., 2006; Salustri et al., 2010). Therefore, establishing the levels and limits of heavy metal contamination in street dust, as well as identifying the sources of heavy metals and the risk to human health in each city, is of utmost importance to propose solution action plans.

Mexico City is one of the largest and most populous cities in the world, with high levels of contamination that cause different health problems, e.g., DNA damage, as well as respiratory and cardiovascular diseases (Son et al., 2018). The study of heavy metals in street dust, with a large number of samples, will make it possible to propose an official standard for Mexico City to define categories of action according to different contamination limits. The objectives of this study were (a) the identification of the levels of heavy metal contamination in street dust, (b) elucidate the possible sources of heavy metals, and (c) human health risk assessment by the heavy metals in street dust of Mexico City.

\section{Materials and methods}

\section{Study site and sampling design}

Mexico City is located in a basin at an altitude of $2240 \mathrm{~m}$ above sea level, with an area of $1485 \mathrm{~km}^{2}$. The population stands at around 8.9 million inhabitants with a population density of 5966 inhabitants $/ \mathrm{km}^{2}$. Considering the metropolitan area, the population reaches 23,500,000 inhabitants. Moreover, $4,000,000$ vehicles circulate every day, and 40,000 small and medium industries are in operation (Molina et al., 2010).

In Mexico City, there are two climatic seasons during the year: the dry winter season from November to April and the rainy season from May to October. During winter, thermal inversions are frequent, until the sun warms the cold air, around 9 or 10 am, the pollutants disperse. The prevailing winds have northeast to southwest direction; however, the "Sierra del Ajusco" prevents the passage of the wind and thus the dispersion of pollutants (Vallejo et al., 2003). An industrial center with a high population density is located in the northern part of the city. The central part includes the historical and socioeconomic center of the city, with a high urban and commercial activity. The southern area has been dominated by residential and commercial activities (Rodríguez-Salazar et al., 2011).

During April and May 2017, a systematic, homogeneously distributed sampling of 482 street dust samples was carried out (Fig. 1). To collect the sample, the dust present in $1 \mathrm{~m}^{2}$ of the street was swept and the geographic coordinates of each site were taken. The samples were transferred to the laboratory where they were allowed to dry at room temperature and in the shade. After that, samples were sieved at $250 \mu \mathrm{m}$, since at this size, the particles adhere easily to the hands and can be ingested (Jadoon et al., 2018).

\section{Geochemical analysis and contamination levels}

To determine heavy metal concentrations, $0.4 \mathrm{~g}$ of each sample was digested with $20 \mathrm{~mL}$ of concentrated $\mathrm{HNO}_{3}$, in an ETHOS Easy microwave digestion system (Millestone Inc) using Teflon PFA beakers. The temperature was brought to $175 \pm 5{ }^{\circ} \mathrm{C}$ in approximately $5 \mathrm{~min}$ and was kept at that temperature for 4.5 min. After cooling, the digested samples were filtered with Whatman No. 42 paper, then transferred into 50-mL flasks, and graduated with water type A (US-EPA method 3051A). Quality controls for the acid digestion method included reagent blanks and sample duplicates. The quality assurance and quality control (QA/QC) results showed no signs of contamination or loss in any of the analyses. 


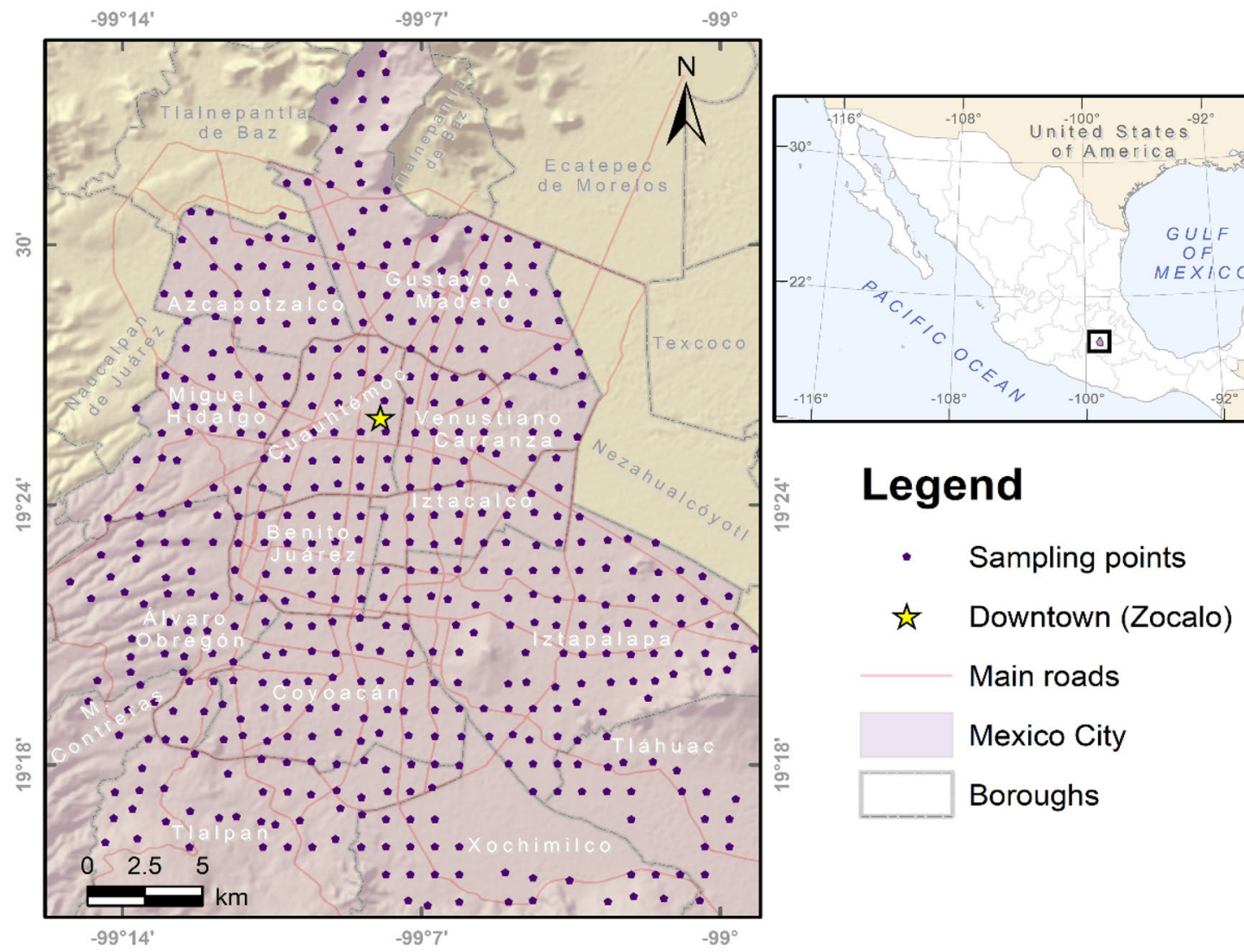

Fig. 1 Location map of the study site and sampling points

Digestions and quality controls were analyzed in triplicate with an Agilent Technologies 5100 Inductively Coupled Plasma Optical Spectrometer (ICPOES) (US: EPA method 6010C). To prepare the calibration curve, multi-elemental QCS-26R referencecertified material was used (high purity brand). Radiofrequency power (RF power) was $1.2 \mathrm{~kW}$, nebulization flow $0.7 \mathrm{~L} / \mathrm{min}$, and argon plasma flow was $12.0 \mathrm{~L} /$ min. The detection (DL) and quantification (QL) limits are presented in Table 1. DL and QL were estimated during validation by measuring low concentration repeats, DL was calculated as 3 times the standard deviation of the repeats, and QL was calculated as 10 times the standard deviation of the same repeats.

Two contamination indexes were calculated for each heavy metal: geoaccumulation index $\left(I_{\text {geo }}\right)$ and contamination factor (CF), as well as the pollution load index (PLI) which is the geometric average of the five highest CF (Eq. 1-3) (Tomlinson et al., 1980).
$I_{\text {geo }}=\log _{2}\left(C_{\mathrm{n}} / 1.5 B_{\mathrm{n}}\right)$

$C F=C_{\mathrm{n}} / B_{\mathrm{n}}$

$P L I=\sqrt[n]{C F 1 * C F 2 * \cdots * C F n}$

$C_{\mathrm{n}}$ represents the concentration of the heavy metal $n$, and $B_{\mathrm{n}}$ is the background geochemical value. Constant 1.5 is used to compensate for natural fluctuations of the heavy metals studied and to compensate for small anthropic influences.

Generally, the background values found in healthy, non-degraded, or managed soils are used as background values; when this information is not available, the global background values for soils have been used (Kabata-Pendias, 2011) or even the minimum value found in the data under study (Declercq et al., 2019). In this research, the 
Table 1 Detection (DL) and quantification (QL) limits for the elements analyzed in the wavelength used by Agilent Technologies 5100 ICP-OES

\begin{tabular}{llcc}
\hline Metal & $\lambda(\mathrm{nm})$ & $\mathrm{DL}(\mathrm{mg} / \mathrm{kg})$ & QL $(\mathrm{mg} / \mathrm{kg})$ \\
\hline $\mathrm{Al}$ & 308.2 & 73.75 & 246.25 \\
$\mathrm{Ba}$ & 233.5 & 2.5 & 7.5 \\
$\mathrm{Ca}$ & 317.9 & 75 & 250 \\
$\mathrm{Co}$ & 228.6 & 1.25 & 5 \\
$\mathrm{Cr}$ & 267.7 & 1.25 & 5 \\
$\mathrm{Cu}$ & 324.7 & 1.25 & 2.5 \\
$\mathrm{Fe}$ & 238.2 & 27.5 & 93.75 \\
$\mathrm{Mg}$ & 279.0 & 52.5 & 177.5 \\
$\mathrm{Mn}$ & 257.6 & 5 & 15 \\
$\mathrm{Ni}$ & 231.6 & 1.25 & 6.25 \\
$\mathrm{~Pb}$ & 220.3 & 3.75 & 15 \\
$\mathrm{~V}$ & 292.4 & 2.5 & 6.25 \\
$\mathrm{Zn}$ & 213.8 & 2.5 & 12.5 \\
\hline
\end{tabular}

first decile was used because no background values have been established for street dust. We use the first decile instead of the minimum value to allow some variation and tolerance. Besides, the global background values for soils were also used, to make comparisons between the two proposals. The interpretation of the $I_{\text {geo }}$ (Müller, 1979) and CF (Ihl et al., 2015) is presented in Table 2. A PLI value close to one indicates that the heavy metal load is close to the bottom level, while a $P L I>1$ indicates contamination (Mehr et al., 2017; Tomlinson et al., 1980).

\section{Sources of heavy metals}

Principal component analysis (PCA) was used as a qualitative pattern recognition method, which can indicate the sources that enrich the concentrations of the heavy metals studied. The PCA reduces the data and extracts a small number of factors (principal components PC), to determine the relationships between the observed variables. The eigenvector with the longest eigenvalue is the direction of greatest variation, the second largest eigenvalue is the orthogonal direction with the next largest variation, and so on. Each PC contains information on all the elements present in a single group, while loads of each element indicate their relative contribution to the formation of the group (Rout et al., 2014).
Table 2 Geoaccumulation index $\left(I_{\text {geo }}\right)$ and contamination factor $(\mathrm{CF})$ interpretation

\begin{tabular}{ll}
\hline$I_{\text {geo }}$ & Interpretation \\
\hline$<0$ & Uncontaminated \\
$0-1$ & Uncontaminated to moderately contaminated \\
$1-2$ & Moderately contaminated \\
$2-3$ & Moderately to highly contaminated \\
$3-4$ & Highly contaminated \\
$4-5$ & Highly to very highly contaminated \\
$>5$ & Very highly contaminated \\
CF & Interpretation \\
$<1$ & Insignificant contamination \\
$1-3$ & Moderate contamination \\
$3-6$ & Considerable contamination \\
$>6$ & High contamination \\
\hline
\end{tabular}

\section{Human health risk by heavy metal contamination in street dust}

To estimate the risk of heavy metals, present in street dust on the health of the population, the methodology developed by the United States Environmental Protection Agency (USEPA) was used. First, the estimated daily intakes for the three main exposure routes were calculated: ingestion $\left(\mathrm{EDI}_{\mathrm{ing}}\right)$, inhalation $\left(\mathrm{EDI}_{\mathrm{inh}}\right)$, and dermal contact $\left(\mathrm{EDI}_{\mathrm{dermal}}\right)$ (Eqs. 4-6), as well as the lifetime average daily dose (LADD) to estimate the carcinogenic risk (Eq. 7).

$$
\mathrm{EDI}_{\text {ing }}=\frac{C \times \operatorname{IngR} \times E F \times E D \times C F}{B W \times A T}
$$

$$
\begin{aligned}
& \mathrm{EDI}_{\text {inh }}=\frac{C \times I n h R \times E F \times E D}{P E F \times B W \times A T} \\
& \mathrm{EDI}_{\text {dermal }}=\frac{C \times S A \times A F \times A B S \times E F \times E D \times C F}{B W \times A T}
\end{aligned}
$$

$$
\begin{aligned}
\mathrm{LADD}= & \frac{C}{\mathrm{PEF} \times \mathrm{AT}_{\text {can }}} \\
& \times\left(\frac{\mathrm{CR}_{\text {child }} \times \mathrm{EF}_{\text {child }} \times \mathrm{ED}_{\text {child }}}{\mathrm{BW}_{\text {child }}}\right. \\
& \left.+\frac{\mathrm{CR}_{\text {adult }} \times \mathrm{EF}_{\text {adult }} \times \mathrm{ED}_{\text {adult }}}{\mathrm{BW}_{\text {adult }}}\right)
\end{aligned}
$$


Table 3 Exposure factors of reference populations for human health risk assessment

\begin{tabular}{|c|c|c|c|c|}
\hline \multirow[t]{2}{*}{ Factor } & \multirow[t]{2}{*}{ Definition and units } & \multicolumn{2}{|l|}{ Value } & \multirow[t]{2}{*}{ Reference } \\
\hline & & Child & Adult & \\
\hline IngR & Ingestion rate (mg/day) & 200 & 100 & USEPA (2001) \\
\hline $\operatorname{InhR}$ & Inhalation rate $\left(\mathrm{m}^{3} /\right.$ day $)$ & 7.63 & 12.8 & Li et al. (2001) \\
\hline PEF & Particle emission factor & $1.36 \mathrm{E}+09$ & $1.36 \mathrm{E}+09$ & USEPA (2001) \\
\hline SA & Surface of exposed skin area $\left(\mathrm{cm}^{2}\right)$ & 2800 & 5700 & USEPA (2001) \\
\hline ABS & Dermal absorption factor & 0.001 & 0.001 & USEPA (2001), Ali et al. (2017) \\
\hline $\mathrm{AF}$ & Skin adherence factor $\left(\mathrm{mg} / \mathrm{cm}^{2}\right)$ & 0.2 & 0.07 & USEPA (2001) \\
\hline ED & Duration of exposure (years) & 6 & 24 & USEPA (2001) \\
\hline EF & Frequency of exposure (days/year ${ }^{1}$ ) & 350 & 350 & Zheng et al. (2010) \\
\hline AT & Average time non-carcinogens (days) & $\mathrm{ED} * 365$ & $\mathrm{ED} * 365$ & USEPA (1989) \\
\hline Atcan & Average time for carcinogens (days) & $70 * 365$ & $70 * 365$ & USEPA (1989) \\
\hline BW & Body weight (kg) & 15 & 70 & $\begin{array}{l}\text { Zheng et al. (2010), Mohmand } \\
\text { (2015), Kurt-Karakus (2012) }\end{array}$ \\
\hline $\mathrm{C}$ & Heavy metal concentration (mg/kg) & This study & & \\
\hline $\mathrm{CF}$ & Conversion factor $(\mathrm{kg} / \mathrm{mg})$ & $1 \times 10^{-6}$ & & Li et al. (2001) \\
\hline
\end{tabular}

All the exposure factors used in this study are those established for reference populations (Table 3). The use of local factors could improve the reliability of the model; however, exposure factors have not been estimated yet for any Mexican City. CR is the contact (or absorption) rate. $\mathrm{CR}=\mathrm{IngR}$ for ingestion, $\mathrm{CR}=\mathrm{InhR}$ for inhalation, and $\mathrm{CR}=\mathrm{SA} \times \mathrm{AF} \times \mathrm{ABS}$ for dermal contact. The type of CR used for each carcinogenic metal depends on the exposure route by which it can cause cancer (Table 4).

Risk ratios for ingestion, inhalation, and dermal contact $\left(\mathrm{HQ}_{\mathrm{ing} / \mathrm{inh} / \mathrm{derm}}\right)$ were obtained by dividing the $E D I$ by the reference dose $(R f D)$ as shown in Eq. 8:

$\mathrm{HQ}_{\text {ing/inh } / \text { derm }}=\frac{\mathrm{EDI}_{\mathrm{ing} / \mathrm{inh} / \mathrm{derm}}}{\mathrm{RfD}}$
The hazard index (HI) represents the sum of the $H Q \mathrm{~s}$ for the three routes of exposure. If $\mathrm{HI}$ is greater than 1, non-carcinogenic effects on the health of the population could occur; if it is less than 1, the opposite would be expected (USEPA, 2001).

For carcinogenic elements, the incremental lifetime cancer risk (ILCR) is commonly calculated using the following equation:

\section{$\mathrm{ILCR}=\mathrm{LADD} \times \mathrm{CSF}$}

The accepted or tolerable risk is in the range of 1E-06 to 1E-04 (USEPA, 2001). These values indicate that an additional case in a population of 1,000,000 and 10,000 people is acceptable ( $\mathrm{Lu}$ et al., 2014).
Table 4 Reference doses (RfD) and cancer slope factor (CSF) for each route of exposure

\begin{tabular}{lllllll}
\hline & Oral RfD & Inhalation RfD & Dermal RfD & Oral CSF & Dermal CSF & Inhalation CSF \\
\hline $\mathrm{Co}$ & $2.00 \mathrm{E}-02$ & $5.71 \mathrm{E}-06$ & $1.60 \mathrm{E}-02$ & & $9.80 \mathrm{E}+00$ \\
$\mathrm{Cr}$ & $3.00 \mathrm{E}-03$ & $2.86 \mathrm{E}-05$ & $6.00 \mathrm{E}-05$ & & $4.20 \mathrm{E}+01$ \\
$\mathrm{Cu}$ & $4.00 \mathrm{E}-02$ & $4.02 \mathrm{E}-02$ & $1.20 \mathrm{E}-02$ & & \\
$\mathrm{Fe}$ & $8.40 \mathrm{E}+00$ & $2.20 \mathrm{E}-04$ & $7.00 \mathrm{E}-02$ & & \\
$\mathrm{Mn}$ & $4.60 \mathrm{E}-02$ & $1.43 \mathrm{E}-05$ & $1.85 \mathrm{E}-03$ & & \\
$\mathrm{Ni}$ & $2.00 \mathrm{E}-02$ & $2.06 \mathrm{E}-02$ & $5.40 \mathrm{E}-03$ & & \\
$\mathrm{~Pb}$ & $3.50 \mathrm{E}-03$ & $3.52 \mathrm{E}-03$ & $5.25 \mathrm{E}-04$ & 0.0085 & \\
$\mathrm{~V}$ & $7.00 \mathrm{E}-03$ & $7.00 \mathrm{E}-03$ & $7.00 \mathrm{E}-05$ & & \\
$\mathrm{Zn}$ & $3.00 \mathrm{E}-01$ & $3.00 \mathrm{E}-01$ & $6.00 \mathrm{E}-02$ & & \\
\hline
\end{tabular}




\section{Results}

\section{Contamination levels by heavy metals in street dust in Mexico City}

All the analyzed elements ( $\mathrm{Ba}, \mathrm{Co}, \mathrm{Cr}, \mathrm{Cu}, \mathrm{Mn}, \mathrm{Ni}, \mathrm{Pb}$, $\mathrm{Ti}, \mathrm{V}, \mathrm{Zn}, \mathrm{Al}, \mathrm{Ca}, \mathrm{Fe}$, and $\mathrm{Mg}$ ) had an asymmetric distribution (not normal) according to the Shapiro test; therefore, the median is used as a reference of central tendency. The median concentrations of the elements decreased in the order $\mathrm{Ca}>\mathrm{Al}>\mathrm{Mg}>\mathrm{Fe}>\mathrm{Ti}>\mathrm{Zn}>\mathrm{Mn}>\mathrm{Ba}>\mathrm{Pb}>\mathrm{C}$ $\mathrm{u}>\mathrm{Cr}>\mathrm{Ni}>\mathrm{V}>\mathrm{Co}$ (Table 5). The first five elements and the $\mathrm{Mn}$ are considered as major elements because they are more abundant in the Earth's crust, while the rest are called trace elements due to their small concentrations.

Both the lack of normality in the frequency distribution and the wide differences between the mean and the median are considered qualitative indicators of the anthropic origin of the elements. The elements that showed the greatest differences between the mean and the median were $\mathrm{Fe}, \mathrm{Pb}, \mathrm{Cu}, \mathrm{Zn}, \mathrm{Al}, \mathrm{Cr}, \mathrm{V}$, and $\mathrm{Ca}$. Besides, the highest coefficients of variation corresponded to $\mathrm{Fe}, \mathrm{Pb}, \mathrm{Zn}, \mathrm{Cu}$, and $\mathrm{Cr}$. These characteristics are the first indications that the concentrations of these elements have been enriched by the anthropic activities in Mexico City. This is logical due to the widespread use of these elements. Especially, these elements are related to the vehicle fleet, body materials, auto part wear, brake lining, motor body, wear and tear of the tire, and other parts (Rahman et al., 2019; Jiang et al., 2018).
Table 6 also summarizes the descriptive statistics of the loadings of the analyzed elements. The loadings were obtained by multiplying the concentrations of each element by the amount of dust, in $\mathrm{kg}$, present on $1 \mathrm{~m}^{2}$ of the surface. None of the loads had a normal distribution, according to the Shapiro test. The medians decreased in the same order as the concentrations of the elements: $\mathrm{Ca}>\mathrm{Al}>\mathrm{Mg}>\mathrm{Fe}>\mathrm{Ti}>\mathrm{Zn}>\mathrm{Mn}>\mathrm{B}$ $\mathrm{a}>\mathrm{Pb}>\mathrm{Cu}>\mathrm{Cr}>\mathrm{Ni}>\mathrm{V}>\mathrm{Co}$.

Table 5 shows the global background values for soils, which were used in this study, along with the first decile of the frequency distribution of each element. Comparing both values highlights the fact that the world background values of soils for $\mathrm{Ba}, \mathrm{Mn}, \mathrm{Ti}$, and $\mathrm{V}$ are more than three times greater than the values proposed in this article (first decile); in the case of $\mathrm{Ti}$, it is 27 times greater. This is because these elements are abundant in soils; however, they are not so abundant in street dust. The opposite occurs for $\mathrm{Pb}$ and $\mathrm{Zn}$, the first decile of the frequency distribution is greater than the global background value for soils, which indicates that the $\mathrm{Pb}$ and $\mathrm{Zn}$ of street dust come mainly from anthropic sources.

\section{Contamination factor}

When the first decile was considered as the background value of street dust from Mexico City, most of the data for all the elements were located at the threshold of
Table 5 Statistical summary of the heavy metal concentrations in $\mathrm{mg} /$ $\mathrm{kg}$ and background values
Min minimum, Max maximum, $C V$ coefficient of variation

${ }^{\mathrm{a}}$ Kabata-Pendias (2011)

\begin{tabular}{llrrrrrrr}
\hline Heavy metal & $n$ & \multicolumn{1}{l}{ Min } & Max & Median & Mean & CV & $\begin{array}{l}\text { Back- } \\
\text { ground } \\
\text { decile 1 }\end{array}$ & $\begin{array}{l}\text { Global soils } \\
\text { background } \\
\text { value }\end{array}$ \\
\hline $\mathrm{Ba}$ & 482 & 41.2 & 446.0 & 122.5 & 128.2 & 0.4 & 77.4 & 460.0 \\
$\mathrm{Co}$ & 482 & 2.5 & 82.4 & 7.5 & 7.4 & 0.6 & 5.0 & 11.3 \\
$\mathrm{Cr}$ & 482 & 15.0 & 441.0 & 43.7 & 51.4 & 0.7 & 28.8 & 59.5 \\
$\mathrm{Cu}$ & 482 & 6.2 & 847.1 & 81.2 & 99.7 & 0.8 & 36.2 & 38.9 \\
$\mathrm{Mn}$ & 482 & 100.0 & 990.5 & 223.7 & 235.2 & 0.3 & 166.3 & 488.0 \\
$\mathrm{Ni}$ & 482 & 13.7 & 148.7 & 35.0 & 36.3 & 0.4 & 22.5 & 29.0 \\
$\mathrm{~Pb}$ & 481 & 8.8 & 1907.8 & 101.2 & 128.2 & 1.0 & 38.7 & 27.00 \\
$\mathrm{Ti}$ & 422 & 96.3 & 1677.1 & 365.5 & 412.3 & 0.5 & 254.9 & 7038.0 \\
$\mathrm{~V}$ & 482 & 11.2 & 160.0 & 26.2 & 26.8 & 0.3 & 18.8 & 129.0 \\
$\mathrm{Zn}$ & 482 & 18.7 & 4827.6 & 229.9 & 280.7 & 1.0 & 113.8 & 70.0 \\
$\mathrm{Al}$ & 482 & 2823.6 & $59,285.2$ & 9045.5 & $10,853.3$ & 0.6 & & \\
$\mathrm{Ca}$ & 482 & 1450.0 & $261,937.5$ & $51,411.8$ & $57,430.1$ & 0.6 & & \\
$\mathrm{Fe}$ & 482 & 653.3 & $61,326.8$ & 3817.0 & 5722.2 & 1.0 & & \\
$\mathrm{Mg}$ & 482 & 984.8 & $30,780.7$ & 6484.5 & 6948.9 & 0.5 & & \\
\hline & & & & & & & & \\
\hline
\end{tabular}


Table 6 Statistical summary of the heavy me tal loads in $\mathrm{mg} / \mathrm{m}^{2}$
Min minimum, Max maximum, $C V$ coefficient of variation

\begin{tabular}{lcrrrrr}
\hline Heavy metal load & $n$ & \multicolumn{1}{c}{ Min } & \multicolumn{1}{c}{ Max } & Median & Mean & CV \\
\hline $\mathrm{Ba}$ & 482 & 0.47 & 18.90 & 5.47 & 5.74 & 0.55 \\
$\mathrm{Co}$ & 482 & 0.02 & 3.42 & 0.31 & 0.34 & 0.73 \\
$\mathrm{Cr}$ & 482 & 0.18 & 15.10 & 1.91 & 2.28 & 0.74 \\
$\mathrm{Cu}$ & 482 & 0.12 & 33.12 & 3.50 & 4.45 & 0.87 \\
$\mathrm{Mn}$ & 482 & 0.92 & 33.56 & 9.82 & 10.69 & 0.53 \\
$\mathrm{Ni}$ & 482 & 0.14 & 9.67 & 1.45 & 1.70 & 0.68 \\
$\mathrm{~Pb}$ & 481 & 0.12 & 52.78 & 4.19 & 5.46 & 0.93 \\
$\mathrm{Ti}$ & 422 & 0.96 & 109.31 & 15.49 & 18.69 & 0.71 \\
$\mathrm{~V}$ & 482 & 0.11 & 7.82 & 1.12 & 1.22 & 0.56 \\
$\mathrm{Zn}$ & 482 & 0.42 & 195.29 & 9.99 & 12.25 & 1.00 \\
$\mathrm{Al}$ & 482 & 33.16 & 3346.18 & 399.23 & 481.67 & 0.73 \\
$\mathrm{Ca}$ & 482 & 53.39 & $17,132.74$ & 2138.60 & 2615.96 & 0.82 \\
$\mathrm{Fe}$ & 482 & 6.88 & 2213.50 & 160.70 & 260.51 & 1.13 \\
$\mathrm{Mg}$ & 482 & 13.89 & 1950.83 & 283.55 & 335.01 & 0.74 \\
$\mathrm{Dust}$ load $\left(\mathrm{g} / \mathrm{m}^{2}\right)$ & 482 & 5.4 & 173.3 & 43.00 & 46.40 & 0.5 \\
\hline
\end{tabular}

moderate contamination (Fig. 2). The $\mathrm{Pb}, \mathrm{Cu}$, and $\mathrm{Zn}$ concentrations had the highest $\mathrm{CF}$, the extreme $\mathrm{CF}$ values of these elements $(\mathrm{Pb}, \mathrm{Cu}$, and $\mathrm{Zn})$ were located in the category of high contamination.

When considering as a background value the one established worldwide for soils, then a greater variation in the levels of contamination was observed, between elements. The elements with the highest CFs were $\mathrm{Pb}$ and $\mathrm{Zn}$, with more than $25 \%$ of the data in the category of considerable contamination, followed by $\mathrm{Cu}$ and $\mathrm{Ni}$ with $\sim 50 \%$ of the data in the moderate contamination category. More than $75 \%$ of the $\mathrm{Cr}$, $\mathrm{Co}$, and $\mathrm{Mn}$ data were located in the insignificant contamination category, and practically, all the $\mathrm{Ba}, \mathrm{Ti}$, and $\mathrm{V}$ data were found in the same category (insignificant contamination).

In the case of the PLI for the five elements with the highest $\mathrm{CF}(\mathrm{Pb}, \mathrm{Cu}, \mathrm{Zn} \mathrm{Cr}$, and $\mathrm{Ni}$ ), more than $50 \%$ of the data had a value greater than 1 , both for the first decile and for the global background value for soils, this indicates that street dust from Mexico City is contaminated by heavy metals, regardless of the background value used in this study.

It is difficult to establish the (natural) background values of the elements when it comes to such a mobile matrix, i.e., street dust, located in urban sites full of anthropic activities. Background values of soils may be inappropriate because they are not the only source of heavy metals in street dust and because the particle size at which both matrices are analyzed is very different.
On the other hand, the results of this study show that the use of the first decile can be limiting by homogenizing the variation for the contamination factors.

\section{Geoaccumulation index}

One of the benefits of the geoaccumulation index, regarding the contamination factor, is that it admits small variations in the background values. When using the first decile as the background value, it was observed that about $50 \%$ of the $\mathrm{Pb}, \mathrm{Zn}$, and $\mathrm{Cu}$ data were found in the category of uncontaminated to moderately contaminated; for the rest of the elements, with exception of Mn and V, just over $25 \%$ of the data was located in that category. Only Mn and V had most of the data in the uncontaminated category.

On the other hand, when considering the global background values for soils, the level of $\mathrm{Pb}$ and $\mathrm{Zn}$ contamination increased, compared with what was found with the first decile, with more than $25 \%$ of the data in the category of moderate contamination. Next, about $50 \%$ of the $\mathrm{Cu}$ data was in the uncontaminated to moderately contaminated category. All other elements were located as uncontaminated, in ascending order $\mathrm{Ti}<\mathrm{V}<\mathrm{Ba}<\mathrm{Mn}<\mathrm{Co}<\mathrm{Cr}<\mathrm{Ni}$.

The most polluting elements in urban Mexico City dust were $\mathrm{Pb}$ and $\mathrm{Zn}$, followed by $\mathrm{Cu}$, regardless of the background value used in this work. However, when using the global background value for soils, the level of contamination was higher. Furthermore, 


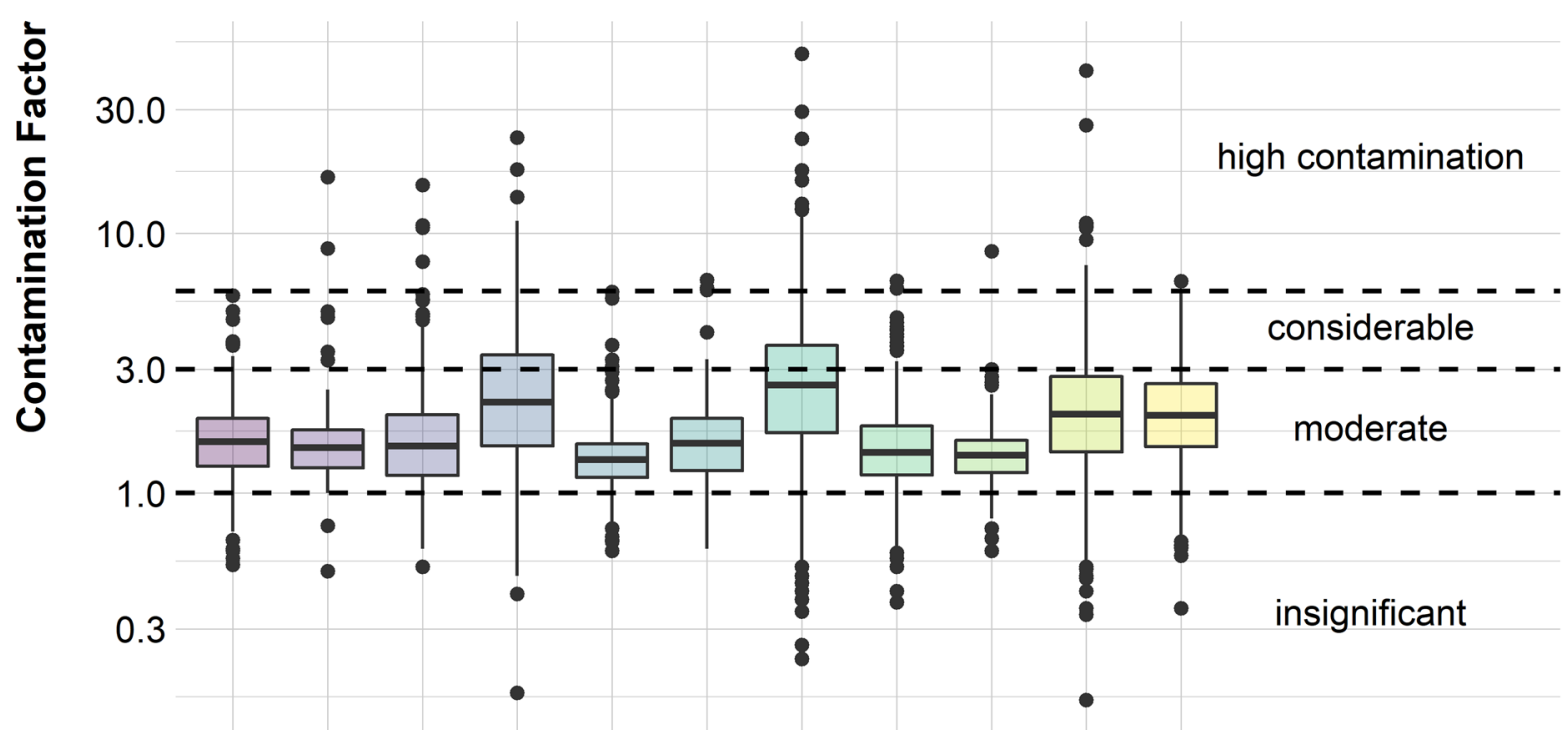

$\mathrm{Ba} \mathrm{Co} \mathrm{Cr} \quad \mathrm{Cu} \quad \mathrm{Mn} \quad \mathrm{Ni} \quad \mathrm{Pb} \quad \mathrm{Ti} \quad \mathrm{V} \quad \mathrm{Zn}$ PLI

Heavy metals

Background Decile 1

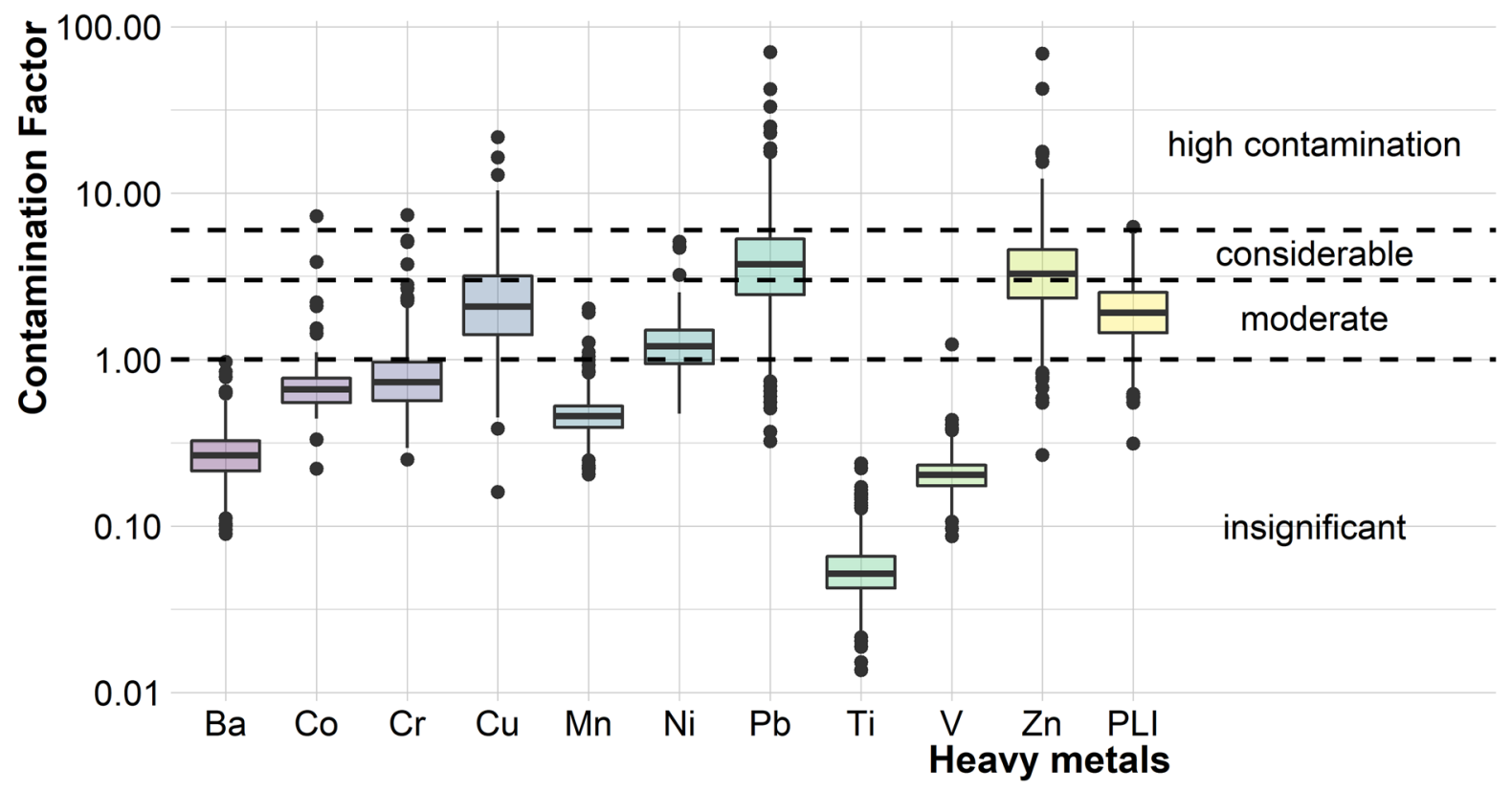

World soil background

Fig. 2 Boxplots for heavy metal contamination factors using the first decile (top image) and the global background value for soils (Kabata-Pendias, 2011) (bottom image) as the background value

even when the median was at an uncontaminated to moderately contaminated level when the first decile was used, and moderately contaminated when the global background value for soils was used; in both cases, some sampled sites reached the category of highly to very highly contaminated by $\mathrm{Pb}$ and $\mathrm{Zn}$. 
Heavy metals with the highest contamination in street dust from Mexico City were $\mathrm{Pb}, \mathrm{Zn}$, and $\mathrm{Cu}$, secondly $\mathrm{Ni}$ and $\mathrm{Cr}$; considering $\mathrm{CF}$ and Igeo, with two different background levels (global value for soils and the first decile). Recognizing that these elements are related to vehicular traffic (Budai \& Clement, 2018; Świetlik et al., 2015; Gunawardena et al., 2014), this sector could be pointed out as one of the most, if not the most influential, in heavy metal contamination in street dust in Mexico City. The PLI (Fig. 2) indicated that the level of contamination by the most polluting heavy metals $(\mathrm{Pb}, \mathrm{Zn}, \mathrm{Cu}, \mathrm{Ni}$, and $\mathrm{Cr}$ ) is moderate, regardless of the background value considered (first decile and world soil background).

\section{Proposal of contamination limits}

The need to establish levels of regulation of heavy metal concentrations in street dust is evident; however, it is a complicated issue, starting with the difficulties of establishing a reference value or background value that represents a state of non-contamination. In the present work, we have compared the $\mathrm{CF}$ and Igeo using two background levels: (1) the first decile of the frequency distribution and (2) the global background value for soils. Each has its advantages and disadvantages; however, we consider that it is more appropriate to use the first decile as it is a specific value for Mexico City.

Using the first decile as the background value, contamination limits were established taking the $\mathrm{CF}$ as a reference (Table 7). The categories proposed for these limits are those used by Galán and Romero (2008) for Spain: (1) reference value $(\mathrm{CF}<1)$ : equivalent to the background value, indicates that there is no contamination below that level. (2) Recommended investigation level (CF: 1-3): there could be an insignificant to moderate degree of contamination, so it is recommended to be alert and, if possible, analyze bioavailable concentrations for the human body. (3) Mandatory investigation level (CF: 3-6): a considerable to a high level of contamination is assumed; therefore, it is considered mandatory to investigate bioavailable concentrations or to carry out a sequential chemical extraction. (4) Intervention level $(\mathrm{CF}>6)$ : a high level of contamination is assumed; therefore, mitigation actions must be carried out to reduce contamination.

The existence of a moderate level of contamination in Mexico City highlights the need to regulate heavy metal concentrations in street dust. The contamination limits are a simple first proposal to start regulating the concentrations of heavy metals in Mexico City. Following the contamination limits proposed in this article, it would be advisable to carry out more exhaustive analyzes on anthropic metals ( $\mathrm{Pb}, \mathrm{Zn}, \mathrm{Cu}, \mathrm{Ni}$, and $\mathrm{Cr}$ ); it is mainly recommended to analyze bioavailable concentrations for humans. Although the contamination limits are based on total concentrations, toxicological analyses are also required. The proposed categories (Galán \& Romero, 2008) allow having a reference on the action measures required at each level of contamination, which is very useful for decision-makers.

\section{Main sources of heavy metals in street dust of Mexico City}

Correlation coefficients have been widely used to identify those elements that came from the same sources. In this study, Spearman's method was used
Table 7 Proposed contamination limits for heavy metals in street dust in Mexico City

\begin{tabular}{lcccc}
\hline Heavy metal & Reference value & $\begin{array}{l}\text { Recommended } \\
\text { investigation level }\end{array}$ & $\begin{array}{l}\text { Mandatory inves- } \\
\text { tigation level }\end{array}$ & Intervention level \\
\hline $\mathrm{Ba}$ & $(\mathrm{mg} / \mathrm{kg})$ & $77-232$ & $232-465$ & $>465$ \\
$\mathrm{Co}$ & 77.4 & $5-15$ & $15-30$ & $>30$ \\
$\mathrm{Cr}$ & 5.0 & $29-86$ & $86-173$ & $>173$ \\
$\mathrm{Cu}$ & 28.8 & $36-109$ & $109-217$ & $>217$ \\
$\mathrm{Mn}$ & 36.2 & $166-499$ & $499-998$ & $>998$ \\
$\mathrm{Ni}$ & 166.3 & $23-67$ & $67-135$ & $>135$ \\
$\mathrm{~Pb}$ & 22.5 & $39-116$ & $116-232$ & $>232$ \\
$\mathrm{Ti}$ & 38.7 & $255-765$ & $765-1529$ & $>1529$ \\
$\mathrm{~V}$ & 254.9 & $19-56$ & $56-113$ & $>113$ \\
$\mathrm{Zn}$ & 18.8 & $114-341$ & $341-683$ & $>683$ \\
\hline
\end{tabular}


as the correlation method, since none of the elements had a normal distribution. $\mathrm{Pb}-\mathrm{Cr}-\mathrm{Cu}-\mathrm{Zn}$ concentrations showed a strong and significant correlation
(Fig. 3), with a coefficient greater than 0.6. The Mn$\mathrm{V}-\mathrm{Al}-\mathrm{Fe}$ also maintained a strong and significant correlation between them. On the other hand, Fe had a

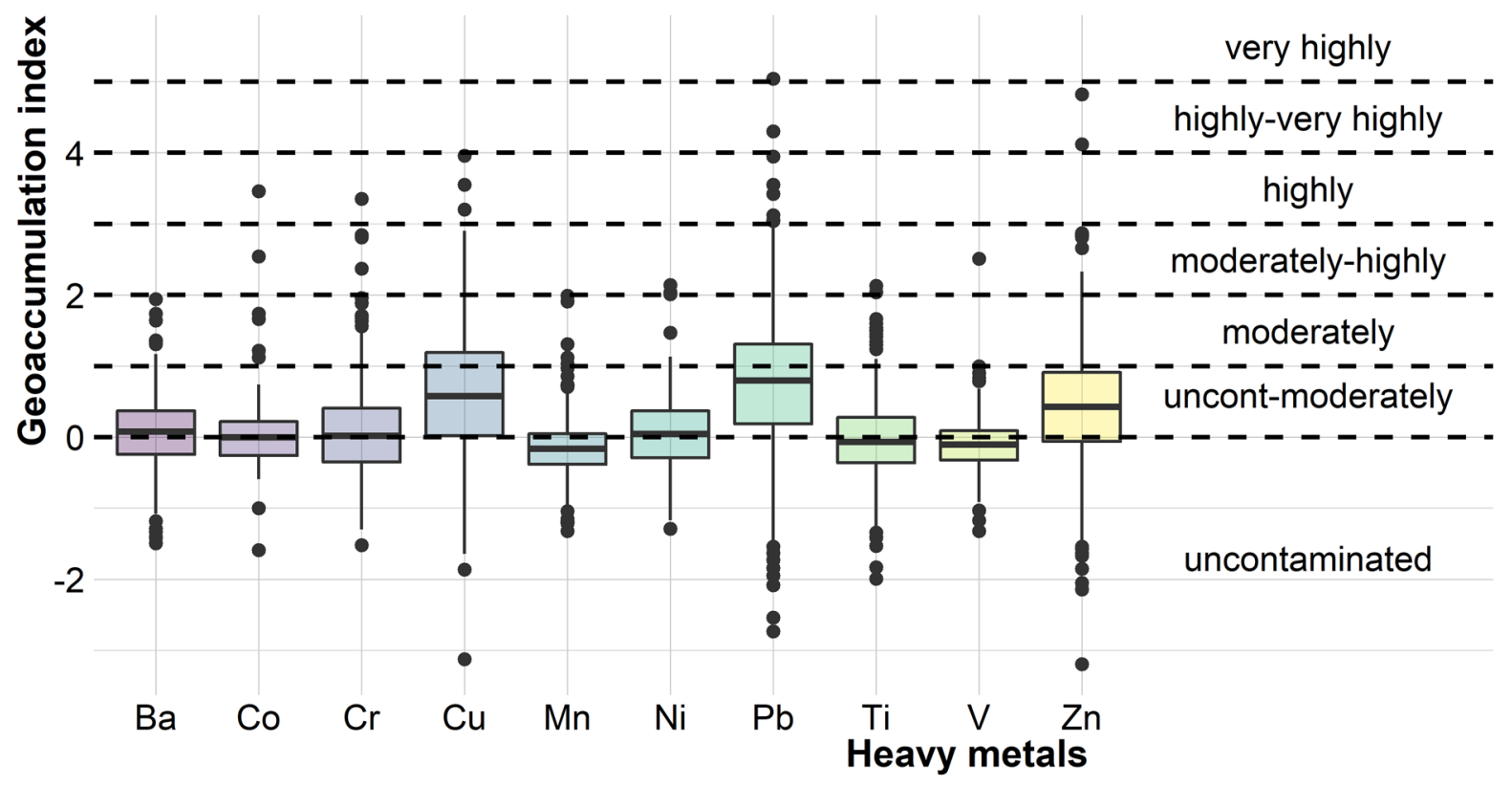

Background Decile 1

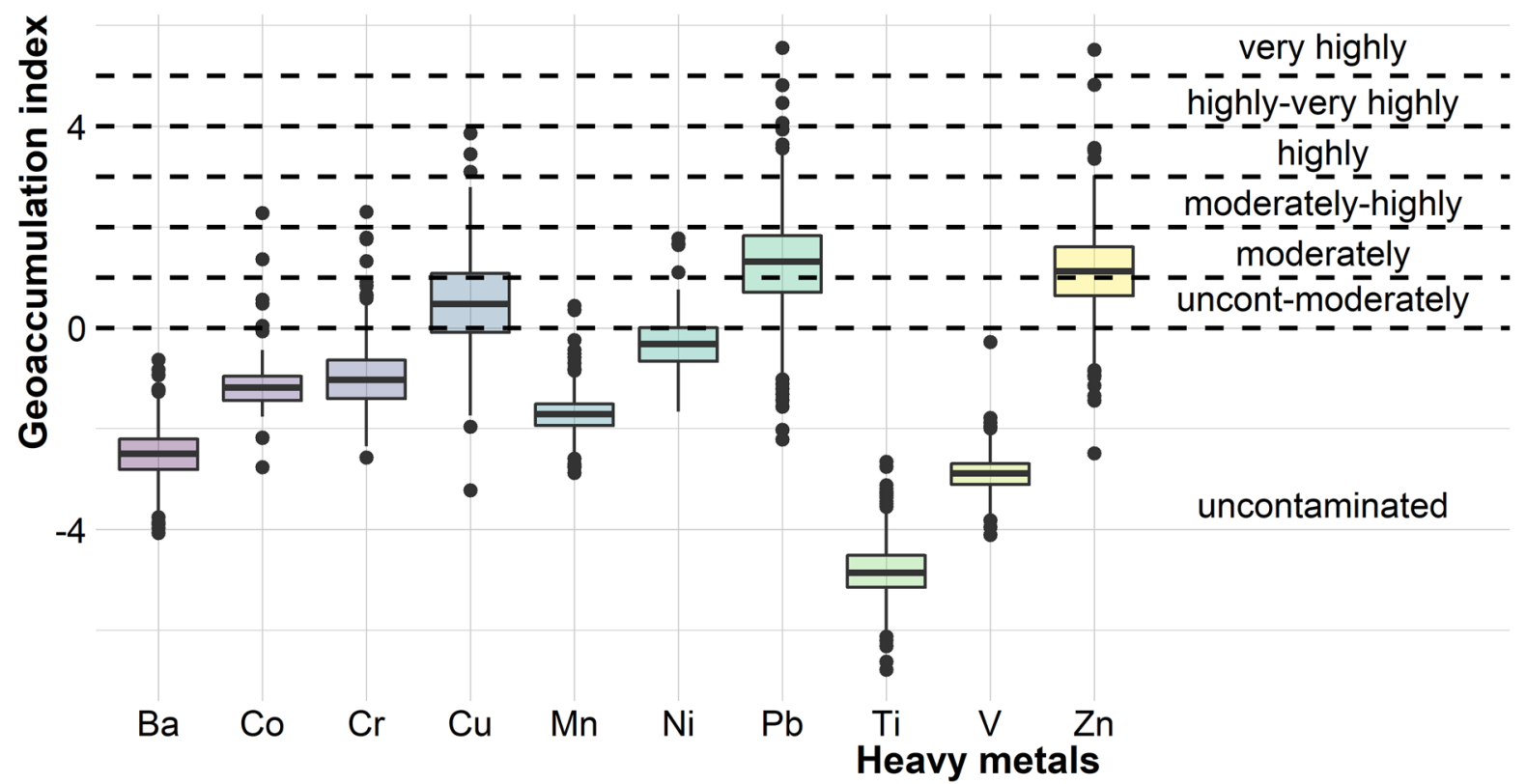

World soil background

Fig. 3 Boxplots for heavy metal geoaccumulation index using the first decile (top image) and the global background value for soils (Kabata-Pendias, 2011) (bottom image) as the background value 
strong and significant, but indirect, relationship with $\mathrm{Ca}, \mathrm{Cr}, \mathrm{Cu}$, and $\mathrm{Ni}$. Also, other significant correlations were found between pairs of elements that can be reviewed in detail in Fig. 4.

The principal component analysis (PCA) was applied on log-transformed data to reduce the influence of high values because data were not normally distributed. Moreover, data were centered and scaled before the analysis was performed. PCA has been a useful method to identify anthropic pollution sources of heavy metals in soils (Liao et al., 2018) and dust (Chen et al., 2014).

The first two PC had eigenvalues greater than one; therefore, they were extracted and are shown in Table 8.
$\mathrm{Mg}, \mathrm{Ca}$, and $\mathrm{Ni}$ concentrations were excluded from the analysis due to poor representability. PC1 explained $40.41 \%$ of data variance and it was dominated by $\mathrm{Fe}$, $\mathrm{Mn}, \mathrm{V}$, and $\mathrm{Al}$; the elements identified as the natural ones. On the other side, PC2 explained $25.9 \%$ of the data variance and it was dominated by the anthropic elements: $\mathrm{Pb}, \mathrm{Cr}, \mathrm{Zn}$, and $\mathrm{Cu}$. These four metals were the most polluting elements of the street dust in Mexico City $(\mathrm{Cr}, \mathrm{Cu}, \mathrm{Pb}$, and $\mathrm{Zn}$ ), according to the contamination indexes previously calculated; this also suggests that they are elements of anthropic origin.

It has been recognized in the literature that $\mathrm{Cu}, \mathrm{Pb}$, $\mathrm{Zn}$, and $\mathrm{Cr}$ are traffic-related metals (Budai \& Clement, 2018; Świetlik et al., 2015; Gunawardena et al., 2014).

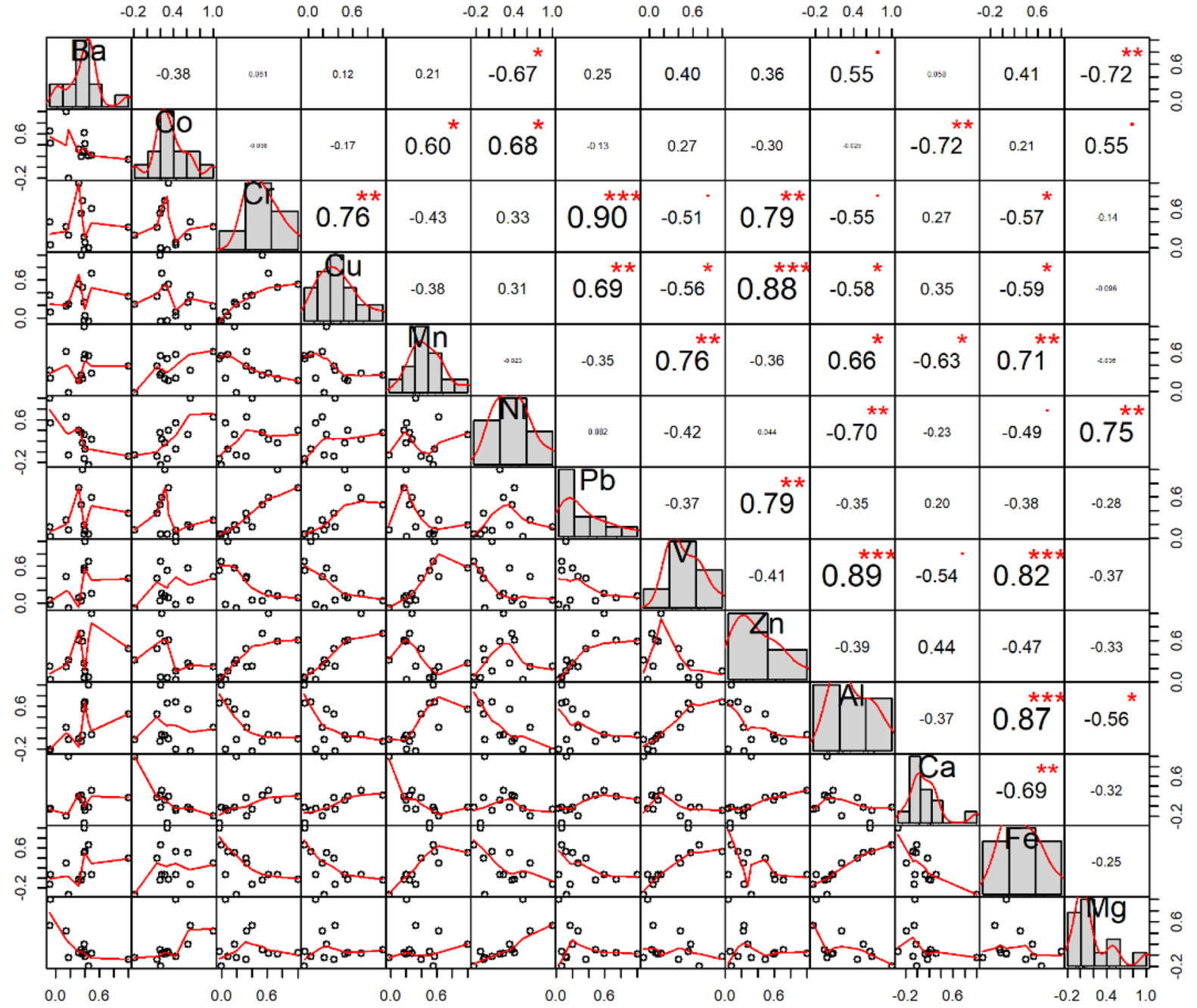

Fig. 4 Spearman correlation coefficients at the top, * indicates statistical significance with $p=0.05$. In the lower part, the scatter plots of the corresponding pairs of variables can be seen 
Table 8 Component matrix for data of Mexico City street dust

\begin{tabular}{lcc}
\hline Elements & Component 1 & $\begin{array}{c}\text { Component 2 } \\
\mathrm{Pb}, \mathrm{Cr}, \mathrm{Zn}, \mathrm{Cu}\end{array}$ \\
\hline $\mathrm{Ba}, \mathrm{Mn}, \mathrm{V}, \mathrm{Al}$ & 0.16 \\
$\mathrm{Co}$ & 0.31 & 0.04 \\
$\mathrm{Cr}$ & 0.31 & 0.40 \\
$\mathrm{Cu}$ & 0.18 & 0.43 \\
$\mathrm{Mn}$ & 0.16 & -0.08 \\
$\mathrm{~Pb}$ & 0.38 & 0.44 \\
$\mathrm{Ti}$ & 0.20 & -0.33 \\
$\mathrm{~V}$ & 0.30 & -0.17 \\
$\mathrm{Zn}$ & 0.38 & 0.43 \\
$\mathrm{Al}$ & 0.20 & -0.29 \\
Fe & 0.35 & -0.19 \\
Eigenvalue & 0.42 & 2.85 \\
Cumulative variance & 40.41 & 66.29 \\
(\%) & 4.45 & \\
\hline
\end{tabular}

Although in varying quantities, $\mathrm{Cu}$ and $\mathrm{Pb}$ emissions are known to originate from brake wear, $\mathrm{Pb}$ can also come from the loss of lead wheel weights, while $\mathrm{Zn}$ is mainly emitted by tire and brakes wear, as well as from diesel exhaust emission, and some $\mathrm{Zn}$ compounds are used as additives for motor oil (Budai \& Clement, 2018; Świetlik et al., 2015). Cr can originate from exhaust emissions (Gunawardena et al., 2014).

In the present study, the results of the Spearman correlation coefficients and PCA showed an association between $\mathrm{Pb}$ and $\mathrm{Cr}$; this has also been previously observed in studies on street dust (Lee et al., 2018; Legalley \& Krekeler, 2013). Lee et al. (2018) concluded that lead chromate in dust particles originates from yellow street paint; furthermore, they argued that the paint containing lead chromate is one of the largest sources of $\mathrm{Pb}$ contamination in street dust; therefore, lead chromate paint could be a probable source of $\mathrm{Pb}$ and $\mathrm{Cr}$ in Mexico City street dust. Once the lead chromate begins to deteriorate due to abrasion, humidity, and temperature, as well as the exposure of the pigments to light (it is a photo-sensitive pigment), paint and pigments crack, peel, and turn to chalk, mobilizing metal particles into the urban environment (Legalley \& Krekeler, 2013).

In Mexico City, only one previous study on heavy metals in street dust has been carried out, whose sampling took place in 2011. Compared with that study, the same heavy metals continue to have the highest degree of contamination: $\mathrm{Cr}, \mathrm{Cu}, \mathrm{Pb}$, and $\mathrm{Zn}$ (Delgado et al., 2019). In comparison with Mexico City soils, previous studies also identified $\mathrm{Pb}, \mathrm{Cu}$, and $\mathrm{Zn}$ as anthropic elements; however, $\mathrm{Cr}$ was considered as a natural element in soils, while in street dust, it seems to be anthropic. In the case of the present study, the very strong Spearman's correlation coefficient $(r=0.9)$ found between $\mathrm{Pb}$, which is consensually anthropic, and $\mathrm{Cr}$ indicates that the origin of $\mathrm{Cr}$ in street dust is mainly anthropic.

\section{Human health risk by heavy metal contamination in street dust}

The evaluation of the health risk using the USEPA methodology showed that the mean concentrations of the elements were within the level considered to be safe for the population health (children and adults). This indicates that there is no risk of developing adverse health effects due to exposure to the analyzed heavy metals $(\mathrm{HI}<1)$ (Table 9).

The average $\mathrm{HI}$ of $\mathrm{Cr}$ and $\mathrm{Pb}$ for children was the closest to the safe limit, being in the order of E-01; at that level, it has been reported that ailments of different types can be triggered (Jadoon et al., 2018). Furthermore, the maximum HIs of $\mathrm{Cr}$ and $\mathrm{Pb}$ can indeed represent a health risk for children exposed to these sites, since they exceed the threshold considered safe. Therefore, attention should be paid to the concentrations of these elements present in street dust; as a conservative action, maximum values should be considered.

The maximum IR $(2.13 \mathrm{E}-05)$ and average $(2.48 \mathrm{E}-$ 06) of $\mathrm{Cr}$ are within the tolerable risk, which means that $\sim 2$ cases of cancer in a population of 100,000 people may occur for the maximum RI, and 2.5 cases in a population of 1 million people may occur for the average RI. However, it depends on the oxidation state, since only $\mathrm{Cr}$ (IV) is carcinogenic, while in this study, the total concentrations were used for the risk assessment. In another study of $\mathrm{Cr}$ in street dust, it was found that around $45 \%$ of the $\mathrm{Cr}$ present in the sample corresponds to Cr (VI) (Lee et al., 2018); if the same occurs for Mexico City, the risk would be reduced in more than a half; however, this should be corroborated in the future. 
Table 9 Hazard indexes (HI) for children and adults and risk index (RI)

\begin{tabular}{|c|c|c|c|c|c|c|}
\hline Heavy metal & Minimum & Maximum & Median & Mean & Standard deviation & $\begin{array}{l}\text { Coefficient } \\
\text { of variation }\end{array}$ \\
\hline & Children & & & & & \\
\hline $\mathrm{Co}$ & $1.76 \mathrm{E}-03$ & $5.81 \mathrm{E}-02$ & $5.28 \mathrm{E}-03$ & $5.26 \mathrm{E}-03$ & $3.12 \mathrm{E}-03$ & $5.94 \mathrm{E}-01$ \\
\hline $\mathrm{Cr}$ & 7.30E-02 & $2.15 \mathrm{E}+00$ & 2.13E-01 & $2.50 \mathrm{E}-01$ & $1.67 \mathrm{E}-01$ & $6.67 \mathrm{E}-01$ \\
\hline $\mathrm{Cu}$ & $2.02 \mathrm{E}-03$ & $2.73 \mathrm{E}-01$ & 2.62E-02 & $3.22 \mathrm{E}-02$ & $2.45 \mathrm{E}-02$ & $7.60 \mathrm{E}-01$ \\
\hline $\mathrm{Fe}$ & 2.39E-03 & $2.25 \mathrm{E}-01$ & $1.40 \mathrm{E}-02$ & $2.10 \mathrm{E}-02$ & 2.13E-02 & $1.02 \mathrm{E}+00$ \\
\hline $\mathrm{Mn}$ & $3.22 \mathrm{E}-02$ & $3.19 \mathrm{E}-01$ & $7.21 \mathrm{E}-02$ & $7.58 \mathrm{E}-02$ & $2.54 \mathrm{E}-02$ & 3.34E-01 \\
\hline $\mathrm{Ni}$ & 8.88E-03 & $9.61 \mathrm{E}-02$ & $2.26 \mathrm{E}-02$ & $2.35 \mathrm{E}-02$ & $8.98 \mathrm{E}-03$ & $3.83 \mathrm{E}-01$ \\
\hline $\mathrm{Pb}$ & $0.00 \mathrm{E}+00$ & $7.10 \mathrm{E}+00$ & 3.77E-01 & 4.75E-01 & $5.01 \mathrm{E}-01$ & $1.05 \mathrm{E}+00$ \\
\hline $\mathrm{V}$ & $2.63 \mathrm{E}-02$ & $3.74 \mathrm{E}-01$ & $6.13 \mathrm{E}-02$ & $6.27 \mathrm{E}-02$ & $2.06 \mathrm{E}-02$ & $3.29 \mathrm{E}-01$ \\
\hline $\mathrm{Zn}$ & $8.10 \mathrm{E}-04$ & $2.09 \mathrm{E}-01$ & $9.94 \mathrm{E}-03$ & $1.21 \mathrm{E}-02$ & $1.27 \mathrm{E}-02$ & $1.05 \mathrm{E}+00$ \\
\hline \multirow[t]{2}{*}{ Sum } & $2.60 \mathrm{E}-01$ & $9.39 \mathrm{E}+00$ & 8.32E-01 & $9.58 \mathrm{E}-01$ & $6.59 \mathrm{E}-01$ & $6.88 \mathrm{E}-01$ \\
\hline & Adults & & & & & \\
\hline Co & $2.28 \mathrm{E}-04$ & 7.54E-03 & $6.85 \mathrm{E}-04$ & $6.82 \mathrm{E}-04$ & 4.05E-04 & $5.94 \mathrm{E}-01$ \\
\hline $\mathrm{Cr}$ & $8.28 \mathrm{E}-03$ & $2.44 \mathrm{E}-01$ & $2.41 \mathrm{E}-02$ & $2.84 \mathrm{E}-02$ & $1.89 \mathrm{E}-02$ & $6.67 \mathrm{E}-01$ \\
\hline $\mathrm{Cu}$ & $2.17 \mathrm{E}-04$ & $2.94 \mathrm{E}-02$ & $2.82 \mathrm{E}-03$ & $3.46 \mathrm{E}-03$ & $2.63 \mathrm{E}-03$ & $7.60 \mathrm{E}-01$ \\
\hline $\mathrm{Fe}$ & $5.40 \mathrm{E}-04$ & $5.07 \mathrm{E}-02$ & $3.16 \mathrm{E}-03$ & 4.73E-03 & $4.81 \mathrm{E}-03$ & $1.02 \mathrm{E}+00$ \\
\hline $\mathrm{Mn}$ & 4.17E-03 & 4.14E-02 & $9.34 \mathrm{E}-03$ & $9.82 \mathrm{E}-03$ & $3.28 \mathrm{E}-03$ & $3.34 \mathrm{E}-01$ \\
\hline $\mathrm{Ni}$ & $9.55 \mathrm{E}-04$ & $1.03 \mathrm{E}-02$ & $2.43 \mathrm{E}-03$ & $2.52 \mathrm{E}-03$ & $9.67 \mathrm{E}-04$ & 3.83E-01 \\
\hline $\mathrm{Pb}$ & $0.00 \mathrm{E}+00$ & 7.67E-01 & 4.07E-02 & $5.13 \mathrm{E}-02$ & $5.41 \mathrm{E}-02$ & $1.05 \mathrm{E}+00$ \\
\hline V & $3.08 \mathrm{E}-03$ & 4.38E-02 & $7.18 \mathrm{E}-03$ & 7.34E-03 & $2.41 \mathrm{E}-03$ & 3.29E-01 \\
\hline $\mathrm{Zn}$ & 8.70E-05 & $2.25 \mathrm{E}-02$ & $1.07 \mathrm{E}-03$ & $1.31 \mathrm{E}-03$ & $1.37 \mathrm{E}-03$ & $1.05 \mathrm{E}+00$ \\
\hline \multirow[t]{2}{*}{ Sum } & $2.92 \mathrm{E}-02$ & $1.03 \mathrm{E}+00$ & 9.57E-02 & $1.10 \mathrm{E}-01$ & $7.26 \mathrm{E}-02$ & $6.63 \mathrm{E}-01$ \\
\hline & Risk index & & & & & \\
\hline $\mathrm{Co}$ & 2.82E-08 & 9.30E-07 & $8.45 \mathrm{E}-08$ & $8.42 \mathrm{E}-08$ & $5.00 \mathrm{E}-08$ & $5.94 \mathrm{E}-01$ \\
\hline $\mathrm{Cr}$ & $7.25 \mathrm{E}-07$ & $2.13 \mathrm{E}-05$ & $2.11 \mathrm{E}-06$ & $2.48 \mathrm{E}-06$ & $1.66 \mathrm{E}-06$ & $6.67 \mathrm{E}-01$ \\
\hline $\mathrm{Ni}$ & $1.33 \mathrm{E}-08$ & $1.44 \mathrm{E}-07$ & $3.38 \mathrm{E}-08$ & $3.51 \mathrm{E}-08$ & $1.35 \mathrm{E}-08$ & $3.83 \mathrm{E}-01$ \\
\hline $\mathrm{Pb}$ & $0.00 \mathrm{E}+00$ & $1.11 \mathrm{E}-07$ & 5.88E-09 & 7.42E-09 & 7.83E-09 & $1.06 \mathrm{E}+00$ \\
\hline Sum & $1.00 \mathrm{E}-06$ & $2.20 \mathrm{E}-05$ & $2.00 \mathrm{E}-06$ & 2.64E-06 & $1.70 \mathrm{E}-06$ & $6.45 \mathrm{E}-01$ \\
\hline
\end{tabular}

\section{Conclusions}

Based on a striking and representative number of samples, the contamination factor and the geoaccumulation index showed that the street dust in Mexico City is moderately contaminated by $\mathrm{Pb}, \mathrm{Zn}$, and $\mathrm{Cu}$. In addition to these three elements, $\mathrm{Cr}$ and $\mathrm{Ni}$, together, were part of the polluting load of street dust, which indicated that more than $90 \%$ of Mexico City was contaminated (polluting load index higher than one). Moreover, the maximum values of $\mathrm{Cr}$ and $\mathrm{Pb}$ concentrations could represent a health risk for children in Mexico City. These results highlight the necessity to monitor and regulate the heavy metals in the street dust; to the best of our knowledge, this regulation is not made anywhere in the world, at the moment.
$\mathrm{Cu}, \mathrm{Cr}, \mathrm{Pb}$, and $\mathrm{Zn}$ in the street dust of Mexico City must have a similar origin since those elements were associated; we assumed they must be anthropic probably due to vehicular traffic, $\mathrm{Cr}$ and $\mathrm{Pb}$ could come from the lead chromate used in the yellow paint, $\mathrm{Cu}$ is known to originate from brake wear, $\mathrm{Zn}$ is emitted by tire and additives to motor oil, and $\mathrm{Cr}$ can originate from exhaust emissions. Fe, Mn, V, and Al must also have a common origin; those can come from natural sources or a mix of natural and anthropic sources. In future studies, it will be important to analyze the possible sources identified in this study; this will be very useful to control the emissions of heavy metals in Mexico City.

With the idea of improving the health of the population of the largest city in the country, we proposed 
categories of action according to the contamination levels identified by the contamination factor; we hope these contamination limits will help to launch public policies to decrease the polluting load of heavy metals in street dust of Mexico City. Government actions are needed around the reduction of emissions, a street dust managing program, and citizen cleaning campaigns, as well as education campaigns on potential health problems due to contact with street dust.

Author contribution All authors contributed to the study conception and design. Data collection was performed by Ruben Cejudo, geochemical analysis was performed by Margarita Gutiérrez-Ruiz and Agueda E. Ceniceros-Gómez. The first draft of the manuscript was written by Anahi Aguilera and all authors commented on previous versions of the manuscript. All authors read and approved the final manuscript.

Funding This study was financially supported by both the National Council of Science and Technology project CB-2016283135 and the project PAPIIT IN209218.

\section{Declarations}

Conflict of interest The authors declare that they have no conflict of interest.

Open Access This article is licensed under a Creative Commons Attribution 4.0 International License, which permits use, sharing, adaptation, distribution and reproduction in any medium or format, as long as you give appropriate credit to the original author(s) and the source, provide a link to the Creative Commons licence, and indicate if changes were made. The images or other third party material in this article are included in the article's Creative Commons licence, unless indicated otherwise in a credit line to the material. If material is not included in the article's Creative Commons licence and your intended use is not permitted by statutory regulation or exceeds the permitted use, you will need to obtain permission directly from the copyright holder. To view a copy of this licence, visit http://creativecommons.org/licenses/by/4.0/.

\section{References}

Aguilera, A., Armendariz, C., Quintana, P., García-Oliva, F., \& Bautista, F. (2019). "Influence of land use and road type on the elemental composition of urban dust in a mexican metropolitan area." Polish Journal of Environmental Studies, 28(3), 1535-1547. https://doi.org/10.15244/pjoes/90358

Aguilar-Reyes, B., Ruiz, R., Martínez-Cruz, J., Bautista, F., Goguitchaichvili, A., Carvallo, C., \& Morales, J. (2012).
Ficus benjamina leaves as indicator of atmospheric pollution: a Reconnaissance study. Studia Geophysica et Geodaetica, 56(3), 879-887. https://doi.org/10.1007/s11200-011-0265-1.

Ali, M. U., Liu, G., Yousaf, B., Abbas, Q., Ullah, H., Munir, M. A. M., \& Fu, B. (2017). Pollution characteristics and human health risks of potentially (Eco)toxic elements (PTEs) in road dust from metropolitan area of Hefei, China. Chemosphere, 181, 111-121. https://doi.org/10.1016/j.chemosphere. 2017.04.061

Budai, P., \& Clement, A. (2018). Spatial distribution patterns of four traffic-emitted heavy metals in urban road dust and the resuspension of brake-emitted particles: findings of a field study. Transportation Research Part D: Transport and Environment, 62, 179-185. https://doi.org/10.1016/j. $\operatorname{trd} .2018 .02 .014$

Calderón, J., Navarro, M. E., Jimenez-Capdeville, M. E., SantosDiaz, M. A., Golden, A., Rodriguez-Leyva, I., et al. (2001). Exposure to arsenic and lead and neuropsychological development in Mexican children. Environmental Research, 85(2), 69-76. https://doi.org/10.1006/enrs.2000.4106.

Carrizales, L., Razo, I., Téllez-Hernández, J. I., Torres-Nerio, R., Torres, A., Batres, L. E., Cubillas, A. C., \& Díaz-Barriga, F. (2006). Exposure to arsenic and lead of children living near a copper-smelter in San Luis Potosi, Mexico: importance of soil contamination for exposure of children. Environmental Research, 101(1), 1-10. https://doi.org/10.1016/j.envres. 2005.07.010

Chen, H., Lu, X., Li, L. Y., Gao, T., \& Chang, Y. (2014). Metal contamination in Campus Dust of Xi'an, China: a study based on multivariate statistics and spatial distribution. Science of the Total Environment, 484(1), 27-35. https://doi. org/10.1016/j.scitotenv.2014.03.026

Cortés, J.L., Bautista, F., Quintana, P., Aguilar, D., \& Goguichaishvili, A. (2015). The color of urban dust as an indicator of contamination by potentially toxic elements: the case of Ensenada, Baja California, Mexico. Revista Chapingo Serie Ciencias Forestales y Del Ambiente XXI, 3, 255-266. https://doi. org/10.5154/r.rchscfa.2015.02.003

Declercq, Y., Samson, R., Castanheiro, A., Spassov, S., Tack, F. M. G., Van De Vijver, E., \& De Smedt, P. (2019). Evaluating the potential of topsoil magnetic pollution mapping across different land use classes. Science of the Total Environment, 685(2019), 345-356. https://doi.org/10.1016/j.scitotenv.2019.05.379

Delgado, C., Bautista, F., Gogichaishvili, A., Cortés, J. L., Quintana, P., Aguilar, D., \& Cejudo, R. (2019). "Identificación de las zonas contaminadas con metales pesados en el polvo urbano de la Ciudad de México." Revista Internacional de Contaminación Ambiental, 35(1), 81-100. https://doi.org/10.20937/ RICA.2019.35.01.06

Galán, E., \& Romero, A. (2008). Contaminación de Suelos Por Metales Pesados. Revista de La Sociedad Española de Mineralogía, 10, 48-60.

Gunawardena, J., Ziyath, A. M., Egodawatta, P., Ayoko, G. A., \& Goonetilleke, A. (2014). Mathematical relationships for metal build-up on urban road surfaces based on traffic and land use characteristics. Chemosphere, 99, 267-271. https://doi. org/10.1016/j.chemosphere.2013.10.068

Ihl, T., Bautista, F., Ruíz, F. R. C., Delgado, M. D. C., Owen, P. Q., Aguilar, D., \& Goguitchaichvili, A. (2015). "Concentration of toxic elements in topsoils of the metropolitan area of Mexico City: A spatial analysis using ordinary kriging and indicator 
kriging." Revista Internacional de Contaminacion Ambiental, 31(1), 47-62. http://www.scielo.org.mx/scielo.php?scrip $\mathrm{t}=$ sci_abstract\&pid=S0188-49992015000100004\& lng=en\&nrm=iso\&tlng=en

Jadoon, W. A., Khpalwak, W., Chidya, R. C. G., Abdel-Dayem, S. M. M. A., Takeda, K., Makhdoom, M. A., \& Sakugawa, H. (2018). Evaluation of levels, sources and health hazards of road-dust associated toxic metals in Jalalabad and Kabul Cities, Afghanistan. Archives of Environmental Contamination and Toxicology, 74(1), 32-45. https://doi.org/10.1007/s00244-017-0475-9

Jiang, Y., Shi, L., Guang, A. L., Mu, Z., Zhan, H., \& Wu, Y. (2018). Contamination levels and human health risk assessment of toxic heavy metals in street dust in an industrial city in Northwest China. Environmental Geochemistry and Health, 40(5), 2007-2020. https://doi.org/10.1007/s10653-017-0028-1

Kabata-Pendias, A. (2011). Trace Elements in Soils and Plants. CRC Press. 4th ed. New York: Taylor and Francis Group, LLC. https://doi.org/10.1201/b10158-25

Kurt-Karakus, P.B., (2012). Determination of heavy metals in indoor dust from Istanbul, Turkey: Estimation of the health risk. Environment International, 50, 47-55. https://doi. org/10.1016/j.envint.2012.09.011

Lee, P. K., Chang, H. J., Yu, S., Chae, K. H., Bae, J. H., Kang, M. J., \& Chae, G. (2018). Characterization of Cr (VI) - containing solid phase particles in dry dust deposition in Daejeon, South Korea. Environmental Pollution, 243, 1637-1647. https://doi. org/10.1016/j.envpol.2018.09.127

Legalley, E., \& Krekeler, M. P. S. (2013). A Mineralogical and geochemical investigation of street sediment near a coal-fired power plant in Hamilton, Ohio: an example of complex pollution and cause for community health concerns. Environmental Pollution, 176, 26-35. https://doi.org/10.1016/j.envpol.2012.12.012

Li, X., Poon, C.S., Liu, P.S., (2001). Heavy metal contamination of urban soils and street dusts in Hong Kong. Applied Geochemistry, 16, 1361-1368.https://doi.org/ 10.1016/S0883-2927(01)00045-2

Liao, X., Zhang, C., Sun, G., Li, Z., Shang, L., Fu, Y., He, Y., \& Yang, Y. (2018). "Assessment of metalloid and metal contamination in soils from Hainan, China." International Journal of Environmental Research and Public Health, 15(3). https://doi. org/10.3390/ijerph15030454

Lu, X., Wu, X., Wang, Y., Chen, H., Gao, P., \& Fu, Y. (2014). Risk assessment of toxic metals in street dust from a medium-sized industrial city of China. Ecotoxicology and Environmental Safety, 106, 154-163. https://doi.org/10.1016/j.ecoenv. 2014.04.022

Men, C., Liu, R., Xu, F., Wang, Q., Guo, L., \& Shen, Z. (2018). Pollution characteristics, risk assessment, and source apportionment of heavy metals in road dust in Beijing, China. Science of the Total Environment, 612, 138-147. https://doi. org/10.1016/j.scitotenv.2017.08.123

Mohmand, J., Eqani, S.A.M.A.S., Fasola, M., Alamdar, A., Mustafa, I., Ali, N., Liu, L., Peng, S., Shen, H., (2015). Human exposure to toxic metals via contaminated dust: Bioaccumulation trends and their potential risk estimation. Chemosphere, 132, 142-151.https://doi.org/10.1016/j.chemosphere. 2015.03.0042015.03.004

Molina, L. T., Madronich, S., Gaffney, J. S., Apel, E., De Foy, B., Fast, J., Ferrare, R., et al. (2010). An overview of the MILAGRO 2006 Campaign: Mexico City emissions and their transport and transformation. Atmospheric Chemistry and Physics, 10(18), 8697-8760. https://doi.org/10.5194/ acp-10-8697-2010

Müller, G. (1979). Schwermetalle in den Sedimenten des RheinsVeranderungenseit. Umsch Wiss Tech, 79(24), 778-783.

Mehr, M. R., Keshavarzi, B., Moore, F., Sharifi, R., Lahijanzadeh, A., \& Kermani, M. (2017). Distribution, source identification and health risk assessment of soil heavy metals in urban areas of Isfahan Province, Iran. Journal of African Earth Sciences, 132, 16-26. https://doi.org/10.1016/j.jafrearsci.2017.04.026

Rahman, M. S., Khan, M. D. H., Jolly, Y. N., Kabir, J., Akter, S., \& Salam, A. (2019). Assessing risk to human health for heavy metal contamination through street dust in the Southeast Asian Megacity: Dhaka, Bangladesh. Science of The Total Environment, 660(April), 1610-1622. https://doi. org/10.1016/j.scitotenv.2018.12.425

Rodríguez-Salazar, M. T., Morton-Bermea, O., Hernández-Álvarez, E., Lozano, R., \& Tapia-Cruz, V. (2011). The study of metal contamination in urban topsoils of Mexico City using GIS. Environmental Earth Sciences, 62(5), 899-905. https://doi. org/10.1007/s12665-010-0584-5

Rout, T. K., Masto, R. E., Padhy, P. K., Ram, L. C., George, J., \& Joshi, G. (2014). Heavy metals in dusts from commercial and residential areas of Jharia Coal Mining Town. Environmental Earth Sciences, 73(1), 347-359. https://doi. org/10.1007/s12665-014-3429-9

Salustri, C., Barbati, G., Ghidoni, R., Quintiliani, L., Ciappina, S., Binetti, G., \& Squitti, R. (2010). Is cognitive function linked to serum free copper levels? A cohort study in a normal population. Clinical Neurophysiology, 121(4), 502-507. https://doi.org/10.1016/j.clinph.2009.11.090

Son, Y., Osornio-Vargas, Á. R., O’Neill, M. S., Hystad, P., TexcalacSangrador, J. L., Ohman-Strickland, P., Meng, Q., \& Schwander, S. (2018). Land use regression models to assess air pollution exposure in Mexico City using finer spatial and temporal input parameters. Science of the Total Environment, 639, 40-48. https:// doi.org/10.1016/j.scitotenv.2018.05.144

Świetlik, R., Trojanowska, M., Strzelecka, M., \& Bocho-Janiszewska, A. (2015). Fractionation and mobility of $\mathrm{Cu}, \mathrm{Fe}, \mathrm{Mn}, \mathrm{Pb}$ and $\mathrm{Zn}$ in the road dust retained on noise barriers along expressway - a potential tool for determining the effects of driving conditions on speciation of emitted particulate metals. Environmental Pollution, 196, 404-413. https://doi.org/10.1016/j.envpol. 2014.10.018

Tomlinson, D. L., Wilson, J. G., Harris, C. R., \& Jeffrey, D. W. (1980). Problems in the assessment of heavy-metal levels in estuaries and the formation of a pollution index. Helgoländer Meeresuntersuchungen, 33(1-4), 566-575. https://doi.org/10.1007/BF02414780

USEPA. (2001). Risk assessment guidance for Superfund (RAGS) volume III - part A: process for conducting probabilistic risk assessment, Appendix B. Vol. III. U.S. Environmental Protection Agency, EPA 540-R-02-002. http://www.epa.gov/sites/ production/files/2015-09/documents/rags3adt_complete.pdf

USEPA, (1989). Risk assessment guidance for superfund (RAGS). Volume I. Human health evaluation manual (HHEM). Part E. Supplemental guidance for dermal risk assessment. U.S. Environmental Protection Agency, EPA/540/1-89/002.

Vallejo, M., Jáuregui-Renaud, K., Hermosillo, A. G., Márquez, M. F., \& Cárdenas, M. (2003). Efectos de la contaminación 
atmosférica en la salud y su importancia en la Ciudad de México. Gaceta Médica de México, 139(1), 57-63.

WHO. (2014). "7 million premature deaths annually linked to air pollution." World Health Organization. March 2014. http://www.who.int/mediacentre/news/releases/2014/airpollution/en/\#

Wijesiri, B., Liu, A., Gunawardana, C., Hong, N., Zhu, P., Guan, Y., \& Goonetilleke, A. (2018). Influence of urbanisation characteristics on the variability of particle-bound heavy metals build-up: a comparative study between China and Australia. Environmental Pollution, 242, 10671077. https://doi.org/10.1016/j.envpol.2018.07.123
Zheng, N., Liu, J., Wang, Q., Liang, Z., (2010). Health risk assessment of arsenic exposure to street dust in the zinc smelting district, Northeast China. Science of the Total Environ, 408, 726-733. https://doi.org/10.1007/s10653-012-9463-1

Publisher's Note Springer Nature remains neutral with regard to jurisdictional claims in published maps and institutional affiliations. 